\title{
Screening for inhibitory effects of crude drugs on furin-like enzymatic activities
}

\author{
Yuka Kiba $^{1} \cdot$ Rio Oyama ${ }^{2} \cdot$ Sae Misawa ${ }^{2} \cdot$ Takashi Tanikawa $^{3} \cdot$ Masashi Kitamura $^{1} \cdot$ Ryuichiro Suzuki $^{2}$
}

Received: 19 February 2021 / Accepted: 16 April 2021 / Published online: 30 April 2021

(c) The Japanese Society of Pharmacognosy 2021

\begin{abstract}
The spike (S) protein of severe acute respiratory syndrome coronavirus 2 (SARS-CoV-2) contains a cleavage motif R-X$\mathrm{X}-\mathrm{R}$ for furin-like enzymes at the boundary of the S1/S2 subunits. The cleavage of the site by cellular proteases is essential for $\mathrm{S}$ protein activation and virus entry. We screened the inhibitory effects of crude drugs on in vitro furin-like enzymatic activities using a fluorogenic substrate with whole-cell lysates. Of the 124 crude drugs listed in the Japanese Pharmacopeia, aqueous ethanolic extract of Cnidii Monnieris Fructus, which is the dried fruit of Cnidium monnieri Cussion, significantly inhibited the furin-like enzymatic activities. We further fractionated the plant extract and isolated the two active compounds with the inhibitory activity, namely, imperatorin and osthole, whose $\mathrm{IC}_{50}$ values were $1.45 \mathrm{mM}$ and $9.45 \mu \mathrm{M}$, respectively. Our results indicated that Cnidii Monnieris Fructus might exert inhibitory effects on furin-like enzymatic activities, and that imperatorin and osthole of the crude drug could be potential inhibitors of the motif cleavage.
\end{abstract}

Keywords Furin $\cdot$ Proprotein convertase $\cdot$ SARS-CoV-2 $\cdot$ Coumarin $\cdot$ Imperatorin $\cdot$ Osthole

\section{Introduction}

In December 2019, a novel virus, severe acute respiratory syndrome coronavirus 2 (SARS-CoV-2), belonging to the human coronavirus family, was identified in Hubei Province, China [1]. It causes coronavirus disease 2019 (COVID-19), a severe respiratory disease associated with a high mortality rate. According to the World Health Organization 2019 situation report of February 16, 2021, more than 100,000,000 patients have been diagnosed with COVID-19 and 2,300,000

Masashi Kitamura

kitamura@josai.ac.jp

Ryuichiro Suzuki

ryu_suzu@josai.ac.jp

1 Laboratory of Pharmacognocy, School of Pharmacy, Faculty of Pharmacy and Pharmaceutical Sciences, Josai University, 1-1, Keyakidai, Sakado, Saitama 350-0295, Japan

2 Laboratory of Natural Products and Phytochemistry, Department of Pharmaceutical Sciences, Faculty of Pharmacy and Pharmaceutical Sciences, Josai University, 1-1, Keyakidai, Sakado, Saitama 350-0295, Japan

3 Laboratory of Nutri-Pharmacotherapeutics Management, School of Pharmacy, Faculty of Pharmacy and Pharmaceutical Sciences, Josai University, 1-1, Keyakidai, Sakado, Saitama 350-0295, Japan have died worldwide. The entry of coronavirus into host cells is mediated by the spike (S) protein [2]. Processing of the $\mathrm{S}$ protein by cellular proteases, such as transmembrane protease serine 2 (TMPRSS2), cathepsin, and furin is necessary for protein activation and virus entry [3]. The $S$ protein of SARS-CoV-2 consists of the $\mathrm{NH}_{2}$-terminal S1 domain and $\mathrm{COOH}$-terminal $\mathrm{S} 2$ domain $[2,3]$. The $\mathrm{S} 1$ domain has a receptor-binding domain (RBD) that binds to the host angiotensin-converting enzyme 2 (ACE2) receptor and the S2 domain has an fusion peptide (FP) domain that mediates membrane fusion. The $\mathrm{S}$ protein cleavage at the $\mathrm{S} 1 / \mathrm{S} 2$ boundary by host cell protease plays a key role in binding the ACE2 receptor to the $\mathrm{S} 1$ domain. The S protein of SARS$\mathrm{CoV} 2$ has a cleavage motif $\mathrm{R}-\mathrm{X}-\mathrm{X}-\mathrm{R}$ for furin-like enzymes at the $\mathrm{S} 1 / \mathrm{S} 2$ boundary, matching the consensus amino acid motif of the substrate for furin and related proprotein convertases (PCs) [2, 3]. Furin/PC inhibitors block SARS$\mathrm{CoV}-2 \mathrm{~S}$ protein cleavage to suppress viral entry [2-5]. In addition, SARS-CoV-2 pseudoviruses, which have a mutated $S$ protein at the cleavage site, showed substantially decreased efficiency of entry into host cells [2-4]. Therefore, cleavage inhibitors of the motif site are expected to be therapeutic reagents for SARS-CoV-2 infection [6-8].

Furin, a member of the proprotein convertase family, is ubiquitously expressed in mammalian cells and activates 
various proprotein substrates [9-11]. Furin regulates not only pathogenic pathways but also several physiological pathways, involving hormones, growth factors, adhesion molecules, and cell surface receptors [12]. Furin is involved in calcium-dependent proteolytic cleavage at the $\mathrm{C}$-terminus of a consensus amino acid motif R-X-X-R $\downarrow$ (the arrow indicates the cleavage position) [9].

Peptide-based small molecules, such as hexa-D-arginine (D-6R) and chloromethylketone (CMK) have been reported to be inhibitors of furin and other PCs [13-18]. However, furin/PC-targeting therapeutic reagents for clinical application have not been identified to date. Numerous studies have evaluated furin-like (furin and other PCs) enzymatic activities using a fluorogenic substrate with whole cell lysates and tissue homogenates [19-24]. In this study, the inhibitory effects of crude drugs were evaluated using the furin-like protease assay with a fluorescent peptide substrate.

\section{Materials and methods}

\section{Materials}

We selected 124 crude drugs listed in the Japanese Pharmacopeia, 17th Edition, and purchased them from several distributors (Supplementary Material, Table S1) [25]. Crude drugs $(10 \mathrm{~g})$ were refluxed with $300 \mathrm{~mL}$ of $70 \% \mathrm{EtOH}$ for $1 \mathrm{~h}$, and the resultant extracts were dried by evaporation. The samples were dissolved in dimethyl sulfoxide (DMSO) to a concentration of $10 \mathrm{mg} / \mathrm{mL}$ and stored at $4{ }^{\circ} \mathrm{C}$ until use. Imperatorin and osthole were obtained from Tokyo Chemical Industry Co., Ltd. (Tokyo, Japan) and FUJIFILM Wako Pure Chemical Corporation (Osaka, Japan), respectively.

\section{Furin-like enzyme assay}

A549 cells, human lung carcinoma epithelial cells, were obtained from RIKEN BioResource Center (Tsukuba, Japan) and cultured in Dulbecco's modified Eagle's medium containing $10 \%$ fetal bovine serum, $100 \mu \mathrm{g} / \mathrm{mL}$ streptomycin, and 100 units $/ \mathrm{mL}$ penicillin. A549 cells were seeded in 100 -mm-diameter dishes $\left(1.0 \times 10^{6}\right.$ cells/plate $)$ and cultured for $24 \mathrm{~h}$ at $37{ }^{\circ} \mathrm{C}$ with $5 \% \mathrm{CO}_{2}$. After $24 \mathrm{~h}$, the cells were washed twice with Dulbecco's phosphate-buffered saline (D-PBS). The washed cells were collected in a $1.5-\mathrm{mL}$ tube by scraping and centrifuging at $2000 \times g$ for $2 \mathrm{~min}$. The cells were counted and treated with $1 \mathrm{~mL}$ of $2 \times$ lysis buffer (20 mM HEPES-KOH [pH 7.4], 0.5\% Triton X-100, $1 \mathrm{mM}$ $\mathrm{CaCl}_{2}$ ) per $1.0 \times 10^{6}$ cells. The cell lysates were vortexed for $5 \mathrm{~min}$ and centrifuged at $13,000 \times g$ for $10 \mathrm{~min}$ at $4{ }^{\circ} \mathrm{C}$. The supernatants were transferred to $1.5-\mathrm{mL}$ tubes and stored at $-80{ }^{\circ} \mathrm{C}$ until use. Supernatants $(10 \mu \mathrm{L})$, crude drug extracts $(10 \mu \mathrm{L})$, and $\mathrm{H}_{2} \mathrm{O}(70 \mu \mathrm{L})$ were added to a 96-well black microplate and incubated at $37^{\circ} \mathrm{C}$ for $30 \mathrm{~min}$. Drug extracts were diluted and adjusted to a final concentration of $20 \mu \mathrm{g} /$ $\mathrm{mL}$ for screening. To the mixture, $10 \mu \mathrm{L}$ of $1 \mathrm{mM}$ Pyr-ArgThr-Lys-Arg-methyl-coumaryl-7-amide (pyr-RTKR-MCA) was added (PEPTIDE INSTITUTE, Inc., Osaka, Japan). The mixture was incubated at $37{ }^{\circ} \mathrm{C}$ for $30 \mathrm{~min}$, and fluorescence intensity of the sample was measured with excitation at $380 \mathrm{~nm}$ and emission at $460 \mathrm{~nm}$ using SpectraMax M2 (Molecular Devices, LLC, CA, USA). The 124 samples were subjected to screening using the furin-like enzyme assay, and the results are presented as mean \pm standard deviation of at least three independent experiments. Ethylenediaminetetraacetic acid (EDTA, final conc. $50 \mathrm{mM}$ ) was used as the control in the assay. Half-maximal inhibitory concentration $\left(\mathrm{IC}_{50}\right)$ was obtained by logistic regression analysis using the $d r c$ package for $\mathrm{R}$ [26].

\section{Extraction and isolation of the bioactive compounds}

The dried fruits of Cnidii monnieri (100 g) were extracted three times with $70 \%$ aqueous EtOH ( $1 \mathrm{~h}$, each) under reflux, and the solvent was evaporated in vacuo to obtain the corresponding extract $(55 \mathrm{~g})$. The extract was suspended in water and fractionated with ethyl acetate three times to obtain an ethyl acetate layer. The water-soluble portion was partitioned with $n$-BuOH three times. The yield of ethyl acetate soluble extract and $n-\mathrm{BuOH}$ soluble extract were 4.7 and $1.2 \mathrm{~g}$, respectively. The ethyl acetate soluble extract $(0.3 \mathrm{~g})$ was subjected to chromatography on an ODS column (ODS-SM 50C; Yamazen Corporation, Osaka, Japan) with $\mathrm{MeOH}-\mathrm{H}_{2} \mathrm{O}$ $(4: 1, \mathrm{v} / \mathrm{v})$ as a solvent to yield 16 fractions. Fraction 4 $(12 \mathrm{mg}$ ) was chromatographed on a preparative HPLC column (Senshu Pak ODS-4151-N; $10 \mathrm{~mm} \times 150 \mathrm{~mm}$ ) eluted with $\mathrm{MeOH}-\mathrm{H}_{2} \mathrm{O}(2: 1, \mathrm{v} / \mathrm{v})$ and monitored at $254 \mathrm{~nm}$ to obtain $1(5.2 \mathrm{mg})$. Fraction $6(15 \mathrm{mg})$ was purified by HPLC (Senshu Pak ODS-4151-N; $10 \mathrm{~mm} \times 150 \mathrm{~mm}$ ) with $\mathrm{MeOH}-\mathrm{H}_{2} \mathrm{O}(2.8: 1, \mathrm{v} / \mathrm{v})$ as a solvent, and monitored at $254 \mathrm{~nm}$ to obtain $2(12 \mathrm{mg})$.

\section{Identification}

Compounds $\mathbf{1}$ and $\mathbf{2}$ were identified as imperatorin and osthole, respectively. Their structures were confirmed by comparing their spectroscopic data, such as NMR and MS, with those of authentic compounds.

\section{Results and discussion}

We screened 124 crude drug extracts for inhibitory effects on furin-like activities. The furin-like activity was evaluated using pyr-RTKR-MCA as a fluorogenic substrate and cell lysates as whole proteolytic enzyme. Of the 124 crude 
drug extracts, three extracts, Cnidii Monnieris Fructus (dried fruits of C. monnieri), Hydrangeae Dulcis Folium [dried leaves of Hydrangea macrophylla (Thunb.) Ser. var. thunbergii (Siebold) Makino)], and Forsythiae Fructus [dried fruit of Forsythia suspensa (Thunb.) Vahl] suppressed furinlike activities by more than $40 \%$ (activity: $6.2 \% \pm 0.3 \%$, $56.5 \% \pm 1.8 \%$, and $42.9 \% \pm 2.3 \%$, respectively) (Table 1 ). We then evaluated the $\mathrm{IC}_{50}$ of the three samples and Cnidii Rhizome (the dried rhizome of $C$. officinale) as the control. The $\mathrm{IC}_{50}$ values of Cnidii Monnieris Fructus, Hydrangeae Dulcis Folium, and Forsythiae Fructus were 1.10, 7.12, and $6.52 \mu \mathrm{g} / \mathrm{mL}$, respectively (Table 2). Cnidii Monnieris Fructus showed stronger inhibitory effects on furin-like activity than Cnidii rhizome $\left(\mathrm{IC}_{50}>50 \mu \mathrm{g} / \mathrm{mL}\right)$. Cnidii Monnieri Fructus (Jashoshi in Japanese) has been traditionally used to treat osteoporosis, sexual dysfunction, asthma, and skin ailments [27]. Cnidium monnieri Cusson contains several compounds, such as bergapten, imperatorin, osthole, and xanthotoxin [28]. Here, we fractionated and isolated bioactive compounds from Cnidii Monnieris Fructus contributing to the inhibitory effects on furin-like enzymatic activity. We isolated and identified two coumarin compounds, imperatorin and osthole, with inhibitory activity (Fig. 1). Osthole $\left(\mathrm{IC}_{50}=9.45 \mu \mathrm{M}\right)$ showed significant inhibitory effects on furin-like enzymatic activity when compared with imperatorin $\left(\mathrm{IC}_{50}=1.45 \mathrm{mM}\right)$. The autofluorescence of two coumarins (imperatorin and osthole) did not occur because reaction mixture (compounds and substrates) without cell lysates did not show fluorescence signal. These results indicate that Cnidii Monnieris Fructus might inhibit furin-like enzymatic activities, and that imperatorin and osthole of the crude drug could be candidates for inhibitors of motif cleavage.

In the present study, we screened the anti-furin-like activity of crude drugs using an in vitro furin-like assay with a fluorogenic substrate. Since furin is a $\mathrm{Ca}^{+}-$dependent serine protease, EDTA, a popular chelating agent was used as positive control in this screening. However, a high concentration $\left(\mathrm{IC}_{50} 50 \mathrm{mM}\right)$ was required to exert its inhibitory activities. Although polyphenols, such as tannin is known to show chelating activities, our medicinal plant extracts containing polyphenols did not show inhibitory effects on furin-like activities. It is considered that the concentration of polyphenols in our medicinal extracts was not sufficient to exhibit inhibitory activity. Of the 124 crude drugs, Cnidii Monnieris Fructus showed strong inhibitory effects on furin-like activity, and two coumarin compounds (imperatorin and osthole) exerted inhibitory activity. Further studies are required to understand if Cnidii Monnieris Fructus and its bioactive compounds block S protein processing. For example, the inhibitory effect on $\mathrm{S}$ protein processing could be proven if the $\mathrm{S}$ protein expressed in Escherichia coli is used as a cleavage substrate instead of pyr-RTKR-MCA [29]. When the S protein gene was transfected into mammalian cells, the $S$
Table 1 Screening results of the inhibitory effects of 124 crude drugs on furin-like activity

\begin{tabular}{|c|c|}
\hline Latin Name & Furin-like activity (\%) \\
\hline ACHYRANTHIS RADIX & $95.2 \pm 1.8$ \\
\hline ACONITI RADIX PROCESSA & $72.5 \pm 3.6$ \\
\hline AKEBIAE CAULIS & $92.8 \pm 1.8$ \\
\hline ALISMATIS TUBER & $101.9 \pm 0.7$ \\
\hline ALOE & $83.1 \pm 7.9$ \\
\hline ALPINIAE OFFICINARI RHIZOMA & $92.2 \pm 1.5$ \\
\hline AMOMI SEMEN & $92.6 \pm 2.5$ \\
\hline ANEMARRHENAE RHIZOMA & $95.4 \pm 3.4$ \\
\hline ANGELICAE ACUTILOBAE RADIX & $101.8 \pm 2.3$ \\
\hline ANGELICAE DAHURICAE RADIX & $99.8 \pm 3.1$ \\
\hline ARALIAE CORDATAE RHIZOMA & $60.7 \pm 4.2$ \\
\hline ARCTII FRUCTUS & $97.2 \pm 4.1$ \\
\hline ARECAE SEMEN & $99.2 \pm 2.3$ \\
\hline ARMENIACAE SEMEN & $93.0 \pm 9.7$ \\
\hline ARTEMISIAE CAPILLARIS FLOS & $80.0 \pm 8.3$ \\
\hline ARTEMISIAE FOLIUM & $79.0 \pm 3.8$ \\
\hline ASIASARI RADIX & $78.8 \pm 2.7$ \\
\hline ASPARAGI RADIX & $94.2 \pm 1.1$ \\
\hline ASTRAGALI RADIX & $92.4 \pm 4.6$ \\
\hline ATRACTYLODIS LANCEAE RHIZOMA & $94.4 \pm 3.1$ \\
\hline ATRACTYLODIS RHIZOMA & $84.6 \pm 3.1$ \\
\hline AURANTII FRUCTUS IMMATURUS & $86.3 \pm 2.8$ \\
\hline AURANTII PERICARPIUM & $100.3 \pm 3.8$ \\
\hline BENINCASAE SEMEN & $84.7 \pm 0.3$ \\
\hline BUPLEURI RADIX & $95.0 \pm 2.0$ \\
\hline CANNABIS FRUCTUS & $89.2 \pm 1.7$ \\
\hline CARTHAMI FLOS & $93.7 \pm 5.3$ \\
\hline CASSIAE SEMEN & $83.6 \pm 4.9$ \\
\hline CATALPAE FRUCTUS & $84.8 \pm 2.8$ \\
\hline CHRYSANTHEMI FLOS & $85.3 \pm 4.9$ \\
\hline CIMICIFUGAE RHIZOMA & $96.4 \pm 2.6$ \\
\hline CINNAMOMI CORTEX & $86.9 \pm 5.7$ \\
\hline CITRI UNSHIU PERICARPIUM & $80.8 \pm 2.7$ \\
\hline CLEMATIDIS RADIX & $85.9 \pm 5.6$ \\
\hline CNIDII MONNIERIS FRUCTUS & $6.2 \pm 0.3$ \\
\hline CNIDII RHIZOMA & $103.0 \pm 3.3$ \\
\hline COICIS SEMEN & $93.0 \pm 2.3$ \\
\hline COPTIDIS RHIZOMA & $82.9 \pm 7.5$ \\
\hline CORNI FRUCTUS & $89.8 \pm 1.8$ \\
\hline CORYDALYS TUBER & $86.5 \pm 4.4$ \\
\hline CRATAEGI FRUCTUS & $98.1 \pm 2.4$ \\
\hline CURCUMAE RHIZOMA & $78.2 \pm 1.5$ \\
\hline CYPERI RHIZOMA & $90.0 \pm 0.9$ \\
\hline DIGENEA & $101.1 \pm 3.6$ \\
\hline DIOSCOREAE RHIZOMA & $92.1 \pm 3.0$ \\
\hline EPHEDRAE HERBA & $86.8 \pm 4.7$ \\
\hline EPIMEDII HERBA & $73.4 \pm 11.3$ \\
\hline ERIOBOTRYAE FOLIUM & $79.7 \pm 3.1$ \\
\hline EUODIAE FRUCTUS & $83.1 \pm 2.5$ \\
\hline
\end{tabular}


Table 1 (continued)

\begin{tabular}{|c|c|}
\hline Latin Name & Furin-like activity (\%) \\
\hline FOENICULI FRUCTUS & $79.9 \pm 11.7$ \\
\hline FORSYTHIAE FRUCTUS & $42.9 \pm 2.3$ \\
\hline FRITILLARIAE BULBUS & $90.3 \pm 3.0$ \\
\hline GARDENIAE FRUCTUS & $89.0 \pm 4.2$ \\
\hline GASTRODIA TUBER & $98.9 \pm 2.7$ \\
\hline GENTIANAE RADIX & $101.1 \pm 8.1$ \\
\hline GENTIANAE SCABRAE RADIX & $99.6 \pm 3.3$ \\
\hline GERANII HERBA & $91.2 \pm 12.4$ \\
\hline GINSENG RADIX & $99.5 \pm 4.4$ \\
\hline GINSENG RADIX RUBRA & $97.0 \pm 1.4$ \\
\hline GLYCYRRHIZAE RADIX & $91.3 \pm 4.7$ \\
\hline GLYCYRRHIZAE RADIX PRAEPARATA & $89.3 \pm 1.4$ \\
\hline HOUTTUYNIAE HERBA & $92.9 \pm 11.7$ \\
\hline HYDRANGEAE DULCIS FOLIUM & $56.5 \pm 1.8$ \\
\hline KOI & $95.4 \pm 5.3$ \\
\hline LEONURI HERBA & $67.7 \pm 6.1$ \\
\hline LILII BULBUS & $99.2 \pm 2.6$ \\
\hline LINDERAE RADIX & $67.3 \pm 1.3$ \\
\hline LITHOSPERMI RADIX & $92.2 \pm 4.4$ \\
\hline LONICERAE FOLIUM CUM CAULIS & $94.6 \pm 2.2$ \\
\hline LYCII FRUCTUS & $96.5 \pm 4.8$ \\
\hline MAGNOLIAE CORTEX & $95.8 \pm 4.9$ \\
\hline MAGNOLIAE FLOS & $99.7 \pm 0.5$ \\
\hline MALLOTI CORTEX & $84.2 \pm 8.0$ \\
\hline MENTHAE HERBA & $91.1 \pm 1.9$ \\
\hline MOUTAN CORTEX & $100.4 \pm 2.2$ \\
\hline MYRISTICAE SEMEN & $97.8 \pm 0.5$ \\
\hline NOTOPTERYGII RHIZOMA & $95.3 \pm 10.3$ \\
\hline OPHIOPOGONIS RADIX & $98.3 \pm 1.7$ \\
\hline PAEONIAE RADIX & $95.3 \pm 1.6$ \\
\hline PANACIS JAPONICI RHIZOMA & $85.8 \pm 2.8$ \\
\hline PERILLAE HERBA & $90.1 \pm 1.5$ \\
\hline PERSICAE SEMEN & $95.3 \pm 2.7$ \\
\hline PEUCEDANI RADIX & $103.2 \pm 5.8$ \\
\hline PHARBITIDIS SEMEN & $79.9 \pm 11.2$ \\
\hline PHELLODENDRI CORTEX & $82.1 \pm 6.0$ \\
\hline PICRASMAE LIGNUM & $99.4 \pm 3.0$ \\
\hline PINELLIAE TUBER & $60.7 \pm 3.4$ \\
\hline PLANTAGINIS SEMEN & $98.2 \pm 3.6$ \\
\hline PLATYCODI RADIX & $88.7 \pm 1.4$ \\
\hline POGOSTEMONI HERBA & $83.9 \pm 1.2$ \\
\hline POLYGALAE RADIX & $92.7 \pm 3.3$ \\
\hline POLYGONATI RHIZOMA & $87.6 \pm 9.7$ \\
\hline POLYGONI MULTIFLORI RADIX & $92.1 \pm 6.7$ \\
\hline POLYPORUS & $100.6 \pm 1.7$ \\
\hline PORIA & $93.3 \pm 2.8$ \\
\hline PRUNELLAE SPICA & $93.9 \pm 4.0$ \\
\hline PRUNI CORTEX & $92.2 \pm 13.0$ \\
\hline PUERARIAE RADIX & $92.2 \pm 6.4$ \\
\hline QUERCUS CORTEX & $97.0 \pm 1.7$ \\
\hline
\end{tabular}

Table 1 (continued)

\begin{tabular}{lr}
\hline Latin Name & Furin-like activity $(\%)$ \\
\hline REHMANNIAE RADIX & $94.5 \pm 1.0$ \\
RHEI RHIZOMA & $88.1 \pm 2.6$ \\
RYCII CORTEX & $97.6 \pm 4.1$ \\
SAPOSHNIKOVIAE RADIX & $91.9 \pm 3.5$ \\
SAUSSUREAE RADIX & $79.2 \pm 2.7$ \\
SCHISANDRAE FRUCTUS & $90.4 \pm 1.6$ \\
SCHIZONEPETAE SPICA & $85.2 \pm 6.6$ \\
SCUTELLARIAE RADIX & $87.1 \pm 8.0$ \\
SENNAE FOLIUM & $80.0 \pm 2.4$ \\
SESAMI SEMEN & $95.7 \pm 0.4$ \\
SINOMENI CAULIS ET RHIZOMA & $93.1 \pm 4.4$ \\
SMILACIS RHIZOMA & $90.5 \pm 1.7$ \\
SOPHORAE RADIX & $99.1 \pm 3.9$ \\
SWERTIAE HERBA & $90.8 \pm 4.6$ \\
TRIBULI FRUCTUS & $95.1 \pm 1.8$ \\
TRICHOSANTHIS RADIX & $87.7 \pm 9.2$ \\
UNCARIAE UNCIS CUM RAMULUS & $104.1 \pm 5.8$ \\
UVAE URSI FOLIUM & $89 \pm 6.5$ \\
VALERIANAE FAURIEI RADIX & $90.7 \pm 6.2$ \\
ZANTHOXYLI PIPERITI PERICARPIUM & $82.4 \pm 3.9$ \\
ZEDOARIAE RHIZOMA & $77.1 \pm 3.7$ \\
ZINGIBERIS RHIZOMA & $96.8 \pm 0.5$ \\
ZINGIBERIS RHIZOMA PROCESSUM & $79.4 \pm 6.1$ \\
ZIZYPHI FRUCTUS & $97.7 \pm 3.9$ \\
ZIZYPHI SEMEN & $99.7 \pm 1.7$ \\
& \\
&
\end{tabular}

Ethanol extracts of crude drugs $(20 \mu \mathrm{g} / \mathrm{mL})$ were pre-incubated with cell lysates and added to fluorogenic substrates (pyr-RTKR-MCA). The data are presented as mean \pm standard deviation of at least three independent experiments

Table $2 \mathrm{IC}_{50}$ of different crud drugs

\begin{tabular}{ll}
\hline Sample & $\mathrm{IC}_{50}(\mu \mathrm{g} / \mathrm{mL})$ \\
\hline Cnidii Monnieris Fructus & 1.10 \\
Cnidii Rhizoma & $>50$ \\
Hydrangeae Dulcis Folium & 7.12 \\
Forsythiae Fructus & 6.52 \\
\hline
\end{tabular}

protein was processed by furin/PC, and syncytial phenotype was observed [5, 30]. Evaluation of S protein processing by western blotting and syncytial formation by microscopy would provide direct evidence that the samples affect $\mathrm{S}$ protein processing and virus entry.

Osthole is a multifunctional compound with antioxidative, antiproliferative, anti-inflammatory, and antiallergic properties [31]. A recent study indicated that osthole suppressed TGF- $\beta 1$-induced epithelial-mesenchymal transition (EMT) in lung cancer A549 cells [32]. Because TGF- $\beta 1$ activates furin expression in several cell lines [33, 34], and 


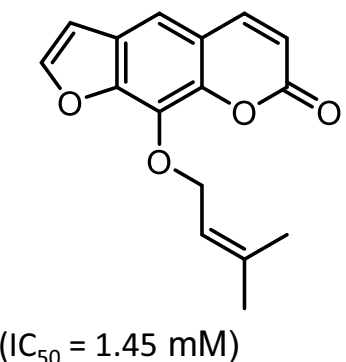

1

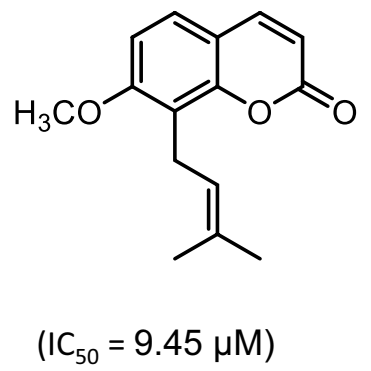

2
Fig. 1 Structure and $\mathrm{IC}_{50}$ of imperatorin (1) and osthole (2)

proteolytic processing of the TGF- $\beta 1$ precursor by furin is an essential step in the formation of biologically active TGF$\beta 1$ [35], osthole might suppress TGF- $\beta 1$-induced autocrine effects by blocking furin-like activities.

In conclusion, we screened the inhibitory effects of 124 crude drugs listed in the Japanese pharmacopoeia on in vitro furin-like enzymatic activities. Of these drugs, Cnidii Monnieris Fructus, which is the dried fruit of $C$. monnieri (Japanese name Jashoshi), strongly inhibited furin-like activity. We further isolated and identified two bioactive coumarins, imperatorin and osthole, from Cnidii Monnieris Fructus.

Supplementary Information The online version contains supplementary material available at https://doi.org/10.1007/s11418-021-01519-9.

\section{Declarations}

Conflict of interest The authors declare no conflict of interest.

\section{References}

1. Chen HD, Luo Y, Guo H, Jiang RD, Liu MQ, Chen Y, Shen XR, Wang X, Zheng XS, Zhao K, Chen QJ, Deng F, Liu LL, Yan B, Zhan FX, Wang YY, Xiao GF, Shi ZL (2020) A pneumonia outbreak associated with a new coronavirus of probable bat origin. Nature 579:270-273

2. Shang J, Wan Y, Luo C, Ye G, Geng Q, Auerbach A, Li F (2020) Cell entry mechanisms of SARS-CoV-2. Proc Natl Acad Sci USA 117:11727-11734

3. Hoffmann M, Kleine-Weber H, Pöhlmann S (2020) A multibasic cleavage site in the spike protein of SARS-CoV-2 is essential for infection of human lung cells. Mol Cell 78:779-784.e5

4. Bestle D, Heindl MR, Limburg H, Van Lam T, Pilgram O, Moulton H, Stein DA, Hardes K, Eickmann M, Dolnik O, Rohde C, Klenk HD, Garten W, Steinmetzer T, Böttcher-Friebertshäuser E (2020) TMPRSS2 and furin are both essential for proteolytic activation of SARS-CoV-2 in human airway cells. Life Sci Alliance 3:e202000786

5. Cheng YW, Chao TL, Li CL, Chiu MF, Kao HC, Wang SH, Pang YH, Lin CH, Tsai YM, Lee WH, Tao MH, Ho TC, Wu PY, Jang LT, Chen PJ, Chang SY, Yeh SH (2020) Furin inhibitors block SARS-CoV-2 spike protein cleavage to suppress virus production and cytopathic effects. Cell Rep 33:108254
6. Wu C, Zheng M, Yang Y, Gu X, Yang K, Li M, Liu Y, Zhang Q, Zhang P, Wang Y, Wang Q, Xu Y, Zhou Y, Zhang Y, Chen L, Li H (2020) Furin: a potential therapeutic target for COVID-19. Science 23:101642

7. AbdelMassih AF, Ye J, Kamel A, Mishriky F, Ismail HA, Ragab HA, El Qadi L, Malak L, Abdu M, El-Husseiny M, Ashraf M, Hafez N, AlShehry N, El-Husseiny N, AbdelRaouf N, Shebl N, Hafez N, Youssef N, Afdal P, Hozaien R, Menshawey R, Saeed R, Fouda R (2020) A multicenter consensus: a role of furin in the endothelial tropism in obese patients with COVID-19 infection. Obes Med 19:100281

8. Adu-Agyeiwaah Y, Grant MB, Obukhov AG (2020) The potential role of osteopontin and furin in worsening disease outcomes in COVID-19 patients with pre-existing diabetes. Cells 9:2528

9. Hatsuzawa K, Nagahama M, Takahashi S, Takada K, Murakami K, Nakayama K (1992) Purification and characterization of furin, a Kex2-like processing endoprotease, produced in Chinese hamster ovary cells. J Biol Chem 267:16094-16099

10. Takahashi S, Nakagawa T, Kasai K, Banno T, Duguay SJ, Van de Ven WJ, Murakami K, Nakayama K (1995) A second mutant allele of furin in the processing-incompetent cell line, LoVo. Evidence for involvement of the homo B domain in autocatalytic activation. J Biol Chem 270:26565-26569

11. Molloy SS, Bresnahan PA, Leppla SH, Klimpel KR, Thomas G (1992) Human furin is a calcium-dependent serine endoprotease that recognizes the sequence Arg-X-X-Arg and efficiently cleaves anthrax toxin protective antigen. J Biol Chem 267:16396-16402

12. Garten W (2018) Characterization of proprotein convertases and their involvement in virus propagation. Activation of viruses by host proteases. Springer International Publishing, pp 205-248

13. Cameron A, Appel J, Houghten RA, Lindberg I (2000) Polyarginines are potent furin inhibitors. J Biol Chem 275:36741-36749

14. Zhou M, Zhang Y, Wei H, He J, Wang D, Chen B, Zeng J, Gong A, Xu M (2018) Furin inhibitor D6R suppresses epithelial-mesenchymal transition in SW1990 and PaTu8988 cells via the HippoYAP signaling pathway. Oncol Lett 15:3192-3196

15. Pang YJ, Tan XJ, Li DM, Zheng ZH, Lei RX, Peng XM (2013) Therapeutic potential of furin inhibitors for the chronic infection of hepatitis B virus. Liver Int 33:1230-1238

16. Zhong M, Munzer JS, Basak A, Benjannet S, Mowla SJ, Decroly E, Chrétien M, Seidah NG (1999) The prosegments of furin and PC7 as potent inhibitors of proprotein convertases. In vitro and ex vivo assessment of their efficacy and selectivity. J Biol Chem 274:33913-33920

17. Jean F, Stella K, Thomas L, Liu G, Xiang Y, Reason AJ, Thomas G (1998) alpha1-Antitrypsin Portland, a bioengineered serpin highly selective for furin: application as an antipathogenic agent. Proc Natl Acad Sci U S A 95:7293-7298

18. Couture F, Kwiatkowska A, Dory YL, Day R (2015) Therapeutic uses of furin and its inhibitors: a patent review. Expert Opin Ther Pat 25:379-396

19. Bourne GL, Grainger DJ (2011) Development and characterisation of an assay for furin activity. J Immunol Methods 364:101-108

20. Loveday EK, Diederich S, Pasick J, Jean F (2015) Human microRNA-24 modulates highly pathogenic avian-origin H5N1 influenza A virus infection in A549 cells by targeting secretory pathway furin. J Gen Virol 96:30-39

21. El Najjar F, Lampe L, Baker ML, Wang LF, Dutch RE (2015) Analysis of cathepsin and furin proteolytic enzymes involved in viral fusion protein activation in cells of the bat reservoir host. PLoS ONE 10:e0115736

22. Leitlein J, Aulwurm S, Waltereit R, Naumann U, Wagenknecht B, Garten W, Weller M, Platten M (2001) Processing of immunosuppressive pro-TGF-beta 1,2 by human glioblastoma cells involves cytoplasmic and secreted furin-like proteases. J Immunol $166: 7238-7243$ 
23. Tellier E, Nègre-Salvayre A, Bocquet B, Itohara S, Hannun YA, Salvayre R, Augé N (2007) Role for furin in tumor necrosis factor alpha-induced activation of the matrix metalloproteinase/sphingolipid mitogenic pathway. Mol Cell Biol 27:2997-3007

24. Sawada Y, Inoue M, Kanda T, Sakamaki T, Tanaka S, Minamino N, Nagai R, Takeuchi T (1997) Co-elevation of brain natriuretic peptide and proprotein-processing endoprotease furin after myocardial infarction in rats. FEBS Lett 400:177-182

25. The Ministry of Health, Labour and Welfare (2016) The Japanese pharmacopoeia. 17th edn (English version). The Ministry of Health, Labour and Welfare, Tokyo

26. Ritz C, Baty F, Streibig JC, Gerhard D (2015) Dose-response analysis using R. PLoS ONE 10:e0146021

27. Baba K, Kawanishi H, Taniguchi M, Kozawa M (1992) Chromones from Cnidium Monnieri. Phytochem 31:1367-1370

28. Liu R, Feng L, Sun A, Kong L (2004) Preparative isolation and purification of coumarins from Cnidium Monnieri (L.) cusson by high-speed counter-current chromatography. J Chromatogr 1055:71-76

29. Örd M, Faustova I, Loog M (2020) The sequence at Spike S1/S2 site enables cleavage by furin and phospho-regulation in SARSCoV2 but not in SARS-CoV1 or MERS-CoV. Sci Rep 10:16944

30. Buchrieser J, Dufloo J, Hubert M, Monel B, Planas D, Rajah MM, Planchais C, Porrot F, Guivel-Benhassine F, Van der Werf S, Casartelli N, Mouquet H, Bruel T, Schwartz O (2020) Syncytia formation by SARS-CoV-2-infected cells. EMBO J 39:e106267
31. Sun Y, Yang AWH, Lenon GB (2020) Phytochemistry, ethnopharmacology, pharmacokinetics and toxicology of Cnidium monnieri (L.) Cusson. Int J Mol Sci 21:1006

32. Feng H, Lu JJ, Wang Y, Pei L, Chen X (2017) Osthole inhibited TGF $\beta$-induced epithelial-mesenchymal transition (EMT) by suppressing NF- $\mathrm{KB}$ mediated Snail activation in lung cancer A549 cells. Cell Adh Migr 11:464-475

33. O'Sullivan MJ, Mitchel JA, Mwase C, McGill M, Kanki P, Park JA (2020) In well-differentiated primary human bronchial epithelial cells, TGF- $\beta 1$ and TGF- $\beta 2$ induce expression of furin. Am J Physiol Lung Cell Mol Physiol 320:246

34. Stawowy P, Margeta C, Kallisch H, Seidah NG, Chrétien M, Fleck E, Graf K (2004) Regulation of matrix metalloproteinase MT1MMP/MMP-2 in cardiac fibroblasts by TGF-beta1 involves furinconvertase. Cardiovasc Res 63:87-97

35. Dubois CM, Blanchette F, Laprise MH, Leduc R, Grondin F, Seidah NG (2001) Evidence that furin is an authentic transforming growth factor-beta1-converting enzyme. Am J Pathol 158:305-316

Publisher's Note Springer Nature remains neutral with regard to jurisdictional claims in published maps and institutional affiliations. 